Article

\title{
Slovak Criminal Justice and the Philosophy of Its Privatization: An Appropriate Solution of Problems of Slovak Justice in the 21st Century?
}

\author{
Bystrík Šramel *, Ján Machyniak and Dušan Gut’an \\ Faculty of Social Sciences, University of ss. Cyril and Methodius in Trnava, 91701 Trnava, Slovakia; \\ jan.machyniak@ucm.sk (J.M.); dusan.gutan@ucm.sk (D.G.) \\ * Correspondence: bystrik.sramel@ucm.sk
}

Received: 19 January 2020; Accepted: 6 February 2020; Published: 8 February 2020

\begin{abstract}
The authors of the paper deal with the philosophy of the privatization of elements of criminal justice, which in the last decades influenced the development of criminal justice in European countries, including the Slovak Republic. The philosophy of privatization in relation to criminal justice represents a wider acceptance of the individual interests of the subjects of criminal procedure. It is the strengthening of powers of the parties to the proceedings and at the same time the entrusting of criminal dispute solution to their own hands. Therefore, the aim of the paper is to examine the expanding philosophy of privatization of the Slovak criminal justice system (the so-called negotiating procedure, a.k.a. plea bargain agreement) which, with the aim of facilitating and simplifying the resolution of a criminal case, has brought the possibility of negotiating with the State the conditions for admitting the guilt of the accused, in exchange for imposing a less severe punishment. However, the aim of the paper is not only to examine the current legal regulation of this expanding phenomenon but also to show its seamy sides and to present comprehensible and reasonable legal opinion relating to its suitability. In the paper, the authors, therefore, deal with the question of whether the philosophy of privatizing the criminal justice is in compliance with the traditional values of the continental legal system. At the same time, they try to answer whether the philosophy of the so-called negotiated justice is not contrary to the fundamental principles of criminal justice. In the paper, the authors also ask questions like: Can the punishment be subject to negotiating? Is it justified on the ground of the society's morality and fundamental values of the legal system if the State negotiates with the perpetrators of crime the conditions of their confession and the length of the punishment? Does the negotiated punishment fulfill its basic functions (preventative, repressive, protective, moral condemnation by society)?
\end{abstract}

Keywords: criminal justice; privatization; negotiated justice; decriminalization; depenalization

\section{Introduction}

Criminal justice is an extremely important part of the Slovak legal order, the purpose of which is to ensure the protection of society against the most serious offenses. Traditionally, the criminal justice system is based on the idea of respecting fundamental human rights and freedoms. It is based on respect and reverence for such values as the value of freedom, equality, and justice. Their expression can be found in the classical principles governing the continental (European) criminal justice system. However, lately, especially since the beginning of the 21st century, the Slovak criminal justice system has been influenced by the privatization philosophy that has penetrated the European legal area. Besides indisputable pragmatic advantages for the State itself, this relatively new philosophy of criminal justice also has seamy sides which can significantly interfere with the system of traditional 
criminal justice and cause the erosion of its basic principles. In this paper, we will try to uncover and point out some of the dangers of the privatization philosophy, its impact on the fundamental values of the Slovak (continental) criminal justice system and examine its impact on the functioning of the classical principles of European criminal justice.

It should be pointed out that Slovak scientific literature deals with the issue of privatization only in the field of economic relations, financial aspects of state bodies or self-government subjects (Horváth et al. 2018; Mihálik et al. 2019). However, the attention of other branches of science (especially legal or political science) to this issue is relatively limited. Slovak legal science only partially deals with the selected elements of privatized criminal justice penetrating the Slovak legal system. The problem, however, is that Slovak authors assume a relatively lax attitude towards the introduction of elements of privatized justice into the Slovak legal order. Consequently, Slovak legal science only superficially deals with the issue in question (privatized justice) and the authors turn only to the description of the conditions of application of privatized legal institutions without further in-depth analysis. In fact, almost all authors deal with only one element of privatized criminal justice-agreement on guilt and punishment. We can only mention a few of the most important authors dealing with the issue. In the context of selected elements of privatized justice (agreement on guilt and punishment), Sojka states that the objective of this element is to speed up criminal proceedings (Sojka 2008). In his paper, the author Mandalik deals with the practical elements of the prosecution procedure from the perspective of the public prosecutor (Mandalík 2006). On the other hand, Žilinka's paper only gives an overview of the possibilities of an alternative way of handling criminal cases. At the same time, he points to the most important changes in legislation (Žilinka 2006). Marková also deals with privatized justice, but she only pays attention in general to trends in diversion proceedings and their possible impact on the empowerment of position and consolidation of influence of the injured and accused on the course of criminal proceedings. In addition, she points out the positives of such a solution to criminal cases (Marková 2005). Vráblová, who discusses plea bargaining procedure in the US criminal law, theoretically defines the concept of a guilt and punishment agreement and describes the process of concluding an agreement on guilt and punishment (Vráblová 2007). The legal regulation of the proceedings on the guilt and punishment agreement is also dealt with by the authors Čentéš and Magvašiová, who, in addition to analyzing the application of this legal institution, also pay attention to statistical indicators concerning the application of this element of privatized justice (Čentéš and Magvašiová 2008). The above-mentioned pair of authors also deal with this issue in another paper in which they examine the knowledge of the application of the guilty and punishment procedure. They point out that in the beginning the institution of the guilt and punishment agreement was not used very often. (Magvašiová and Čentéš 2008).

As can be seen, the existing papers do not pay attention to the fundamental problems arising from the privatized justice and the negatives of this phenomenon. That is why in this paper we look at the phenomenon of privatized criminal justice more closely and through the generalization and abstraction, we are trying to bring new views and opinions to the (essentially nonexistent) scientific debate in the Slovak jurisprudence.

\section{The Philosophy of Privatization and Its Penetration into Slovak Criminal Justice}

Privatization of criminal justice is a law-reform philosophy, the essence of which can be seen in the effort to take greater account of individual interests or in more informal-private access instead of formal-official (Eser 1993). It is the transfer of the criminal-law dispute between the accused and the victim from the public space to the private area. This leads to the strengthening of the autonomy of these parties and to the expansion of the possibilities to directly influence the state's own decision-making process. Therefore, the privatization represents the weakening of the influence of state authorities on 
the course and resolution of the dispute between the accused and the injured. ${ }^{1}$ It is an attempt to bring the criminal procedure closer to the accusation process in its pure form, the substance of which lies in the dispute between the plaintiff-the injured party and the defendant-the perpetrator of the offense.

On the basis of numerous reforms of the criminal justice systems in Europe, it is now possible to state with certainty that the expansion of the philosophy of criminal justice privatization is still more apparent. The reasons that lead the legislators of each continental country to strengthen the influence of procedural parties on the conduct of the proceedings and to weaken the role of the State in the proceedings are directly linked to the problems that continental criminal-law systems have been experiencing in recent decades. European criminal justice systems have come to a state where the fight against crime has become ineffective, slow and falling behind the pace of growing crime. Too much formality, rigidity, or slowness of existing procedural laws, their low flexibility caused the State to fail in its basic role of providing protection to its citizens. The high level of criminalization of anti-social acts has led to a slow criminal-law reaction of the competent state authorities to criminal activity, which also allowed offenders of even serious crimes to avoid adequate sanction for a committed offense. The courts began to be overwhelmed by so-called cases that were unable, due to their number, to properly deal with and to decide within a reasonable time. ${ }^{2}$ This was and is associated with another issue-the disproportionate length of the criminal proceedings, the delays in proceedings.

It should be noted that the growing exercise of the philosophy of privatization of criminal justice represents a major interference with the form of a traditional continental procedure based on the strict application of its two principles - the principles of officiality and legality ${ }^{3}$. Both principles reflect the basic values on which European civilization has been building its legal systems since the 18th century. This includes, in particular, the values of equality of all citizens and fair resolution of disputes. These are the values that were reflected in the continental legal system especially under the influence of the violent revolutionary years of the 18th century, and which express a very fundamental idea that the law should be the same for all, whether it provides protection or punishes (Prusák 2001). All citizens are equal before the law, the law must be equally applicable to all citizens, and cannot be differentiated among citizens, even in relation to access to punishment. The value of justice is reflected in the continental legal order primarily in the so-called legal justice ${ }^{4}$, according to which, the case of a judgment (imposition of sentence) based on inadequate evidence and an incorrect assessment of the facts represents an unfair decision (Klimek 2017). An unfair decision is inherently contradictory to the fundamental interests of the democratic state following the rule of law.

1 In this paper, we understand the privatization of criminal justice as a philosophy of significant and fundamental influence on the course and deciding of the criminal case directly by parties involved in the matter (perpetrator, injured), while the State's influence on the final form of resolving the case is suppressed. In the field of criminal justice, especially in the field of executing a punishment, as well as in the field of securing the national security, privatization has also the form of a philosophy of private companies entering the particular area with a certain "business intention"-e.g., the operation of private prisons on the basis of a contract with the State and an agreed remuneration. In some countries, there is also the operation of private armies (private military companies) that provide the State with appropriate services of public nature. In this sense, many authors, e.g., Bureš, understand privatization as "the transfer of governmental functions fully or partially to the private sector". See closer (Bureš 2013). Privatizace bezpečnosti: České a zahranični zkušenosti (Privatization of security: Czech and foreign experience). Praha: Grada Publishing, p. 37 et seq.

2 What is interesting, the vast majority of these cases, paradoxically, were not the cases of serious criminal offenses, but only simple offences for which the law laid down only moderate punishments.

3 Pursuant to Section 2 (6) of the Slovak Code of Criminal Procedure, the principle of officiality means that law enforcement authorities and courts execute individual acts of criminal proceedings initiatively and conduct criminal prosecution ex offo. Procedures must be taken whenever legal conditions are met and cannot be waived at the request of the parties to the process. Pursuant to Section 2 (5) of the Slovak Code of Criminal Procedure, the principle of legality means that the prosecutor is obliged to prosecute all offenses of which he becomes aware.

4 In addition to legal justice, the value of justice can also be in the form of social justice, ethical justice, dividing and balancing justice. For further details, see (Prusák 2001). Teória práva (Theory of Law). Bratislava: Vydavatel'ské oddelenie PF UK, pp. 25-28. 
However, according to some authors ${ }^{5}$, the principles of officiality and legality, in which the cardinal values of equality and justice are incorporated, are considered to be the causes of disproportionately long criminal proceedings. This view is to a certain extent justified and correctly reflects the nature and consequences of the above-mentioned legal principles. In general, in continental criminal proceedings, law enforcement agencies and courts are required to act on an official basis whenever the conditions are met (the principle of legality). ${ }^{6}$ Individual procedural acts must be carried out independently of other subjects, and the authorities must always act initiatively, independently and may not wait for motions for a procedural act (the principle of officiality). ${ }^{7}$ However, the two principles mentioned above can cause problems especially in those countries where the legislator tries to solve all societal problems with increased criminalization (even minor) anti-social acts. The natural consequence of the impact of these principles is the obligation of the State to prosecute each individual case, even if it is a matter of little importance.

The above-mentioned facts have led the states to the gradual exercise of such a legal philosophy that has allowed (to some extent) to overcome the strict exercise of the principle of officiality and legality and, as a result, to simplify the whole system of criminal justice and make it more effective. For this reason, the states have gradually decided to make certain exceptions to the strict exercise of the traditional principles of the continental criminal procedure, which in particular are the principles of disposition and opportunity. At the same time, according to (Kobor 2008), the ideas of the so-called restorative justice, individual and special prevention have begun to spread. Their essence lied in the belief that the punishment cannot be the purpose itself, but only an instrument for solving social problems. According to the author, the punishment imposed with the consent of the accused serves much better to the interests of justice than the punishment imposed as retaliation. However, we can polemicize with this view. It is questionable whether an agreement on punishment with the defendant or the consent of the accused with the punishment actually allow the achievement of the basic functions (purpose) of the punishment, which according to the traditional legal doctrine are the protective function, the preventive function (individual and general prevention), the repressive function and the function of moral condemnation of the perpetrator by the society.

\section{State as a Justice Dealer?}

One of the most striking manifestations of the philosophy of privatization of Slovak criminal justice has been the so-called negotiating procedure (Plea Bargain Agreement) ${ }^{8}$ which is a legal-philosophical approach to dealing with a criminal case stemming in the Anglo-American legal system. ${ }^{9}$ In spite of the number of its opponents, there is a gradual expansion of this legal institution also in the countries of continental Europe. It is known e.g., in France, Estonia, Germany, Italy, Poland, the Czech Republic. Since the recodification of criminal law in 2005, it has also been exercised in the Slovak Republic.

$5 \quad$ For instance (Küng-Hofer 1984). Die Beschleunigung des Strafverfahrens unter Wahrung der Rechtsstaatlichkeit (Acceleration of criminal proceedings while respecting the rule of law). Bern, Frankfurt/M.: Lang.

6 (Śámal 1999) argues that the principle of legality is a basic condition for ensuring the equality of citizens before the law and the basic precondition for achieving the general preventive effect of deterring others from committing criminality.

7 According to (Musil et al. 2003), the principle of officiality is the basic driving force behind criminal procedure relating to its entire course. It manifests itself from the beginning of the criminal proceedings to its end and prevents crimes from remaining unpunished and at the same time allows the observance of unified rules laid down by the law when conducting criminal prosecution.

8 Pursuant to Section 232 of the Slovak Code of Criminal Procedure, an agreement on guilt and punishment (Plea Bargain Agreement) is understood as an agreement between the prosecutor and the accused, in cases stipulated by law also the injured or other authorized person, on admitting the offense, pleading guilty and accepting punishment by the accused, and possibly other statements. An agreement on guilt and punishment is possible in the prosecution of both minor offences and crimes. Plea Bargain procedure may be initiated if the legal conditions for the opening of proceedings are met. These conditions are met if (a) the results of the investigation or summary investigation justify sufficiently the conclusion that the act is an offense and that the offender has committed it, (b) the defendant has pleaded guilty, (c) the evidence indicates the truthfulness of his guilty plea.

9 In the common law system, this philosophical approach is called "plea bargain". 
The essence of the philosophy on which the plea bargain procedure is based is that the accused under precisely defined conditions pleads guilty and, by agreement with the Public Prosecutor, the accused agrees with the proposed punishment. Thus, the accused renounces his right to a court hearing and the judge imposes the punishment without proving guilt (Čentéš 2008). If we considered the success of the philosophy of negotiated justice in the practice of the Slovak criminal justice authorities during the last years since its implementation, it could be concluded that it has taken well. ${ }^{10}$ This stems in particular from the number of defendants, the cases of which were closed by a motion for the approval of the plea bargain agreement. ${ }^{11}$ Existing statistics help to make the picture of accepting a new philosophy not only by public prosecutors but also by the accused (many motions were initiated by the accused). A number of scientific articles concerning the issue of plea bargain agreement have also been published. These are, for the most part, equally positive to this new philosophy. The practitioners and authors of the publications usually agree that the plea bargain agreement represents, in many ways, a very good way of dealing with criminal matters - they simplify criminal proceedings, in particular, the phases of evidence, they accelerate and make more economically efficient the criminal proceedings. Plea bargain agreements also transform society into a modern open society or society of dialogue. As a result, the conflicting nature of the criminal proceedings is also mitigated and the tasks and activities of the individual procedural parties involved are strengthened. ${ }^{12}$ However, we do not fully identify with these arguments, we do not consider them to be acceptable in their entirety. In the following lines, we will focus our reservations and critical remarks on the arguments in favor of a consensual, privatized solution to the criminal case.

Supporters of the "negotiated justice" philosophy, therefore, argue primarily with pragmatic, economic or rationalization aspects. They state that without granting greater autonomy to procedural parties there will be a disproportionate financial burden on the State budget, which may ultimately lead to the failure of the State to fulfill its essential role. It is this utilitarian attitude that characterizes the Anglo-American criminal justice system philosophy. Many Anglo-American authors, e.g., (Benson 1996), even call for more institutions which are the expression of the philosophy of privatization of criminal justice. ${ }^{13}$ It should be noted that continental authors adhering to the privatization of criminal justice, following the example of the Anglo-American criminal justice system, fail to take account of the overall context or context of the philosophy of the privatization of criminal justice. The understanding of an attitude on criminal justice in the common law system is fundamentally different from the understanding of an attitude on criminal justice in the civil law system. Both systems are based on a certain legal philosophy and reflect certain social demands or social values. Differences can be seen in the philosophical approach to the law itself. While the philosophy of the civil law system answers the question of what is law, the philosophy of the common law system seeks to answer the

10 However, it cannot be said that without any problems. There are still certain problems that need to be solved, especially in relation to the activity of public prosecutors. The fact that the main hearing is not held after reaching plea bargain agreement is not relevant from the perspective of the public prosecutor, since the draft agreement is approved by the court in a public session in which the prosecutor's participation is mandatory. Thus, the negative is that, despite the legislator's efforts to simplify and speed up proceedings, prosecutors spend a relatively huge amount of time at court hearings. Plea bargaining procedure has also led to increased administrative burdens, mainly due to an increase in the administrative agenda, the need to negotiate personally with the accused and others, while the surge in the supply of new criminal matters has remained unchanged. This may also have an impact on the quality of their preparation for the court hearing in other cases.

11 For specific data on the application of the "negotiated justice" philosophy, see the Public Prosecutor's Office Reports 2006-2018 available on the World Wide Web: <https://www.genpro.gov.sk/spravy-o-cinnosti-12b7.html>.

12 See closer e.g., (Musil 2008). Dohody o vině a trestu-ano či ne? Rekodifikácia trestného práva-doterajšie poznatky a skúsenosti (Agreements on guilt and punishment-yes or no? Recodification of criminal law-knowledge and experience to date). Bratislava: Bratislavská vysoká škola práva, pp. 186-89.

13 In his book, the author discusses the various forms of privatization of criminal justice in the Anglo-American legal system. He states that privatization has come to such a stage that in many countries there is not only the widespread use of activities of individual parties to the criminal procedure but also the involvement of private companies in the system of criminal justice. On the basis of a contract with the State, private companies are used for the purpose of providing accommodation for persons executing their imprisonment sentences ("private prisons"). The author considers such privatization trends to be correct, as they make it possible to achieve considerable savings in the State's economy. 
question of how the law works (Pipek 2000). These philosophical attitudes are transformed into the basic philosophical framework in which the criminal justice of individual legal systems is grounded. Although in both legal systems, of course, the primary responsibility for prosecution of crimes is borne by the State and its authorities, the extent of this responsibility is not the same in both legal systems. This is a consequence of the fact that citizens in Europe have entrusted the responsibility for their protection against criminals to the State. The Anglo-American approach, on the other hand, is marked by the weakening of the State's influence on the settlement of the criminal case, mainly because of the stronger sense of citizens' responsibility for their own lives. In addition, the societal view of public authorities, especially public prosecutors, is marked by considerable distrust. (Benson 1996) argues in this respect that public prosecutors are regarded rather as "political animals" that pursue their own interests and interests of strong interest groups and not the interests of the injured. This, of course, is reflected in the principles of disposition and opportunity dominating the Anglo-American criminal justice philosophy.

\section{Is Negotiated Justice Compatible with Traditional Doctrine of Legal Philosophy and Values of European Society?}

The modern common law system is still based on the philosophy of respect for fundamental human rights and freedoms and the protection of the values of freedom, equality, and justice (Jesenková and Jesenko 2015; Szymaniec 2017; Sosnowska et al. 2017). The gradual transfer of the solution of the criminal cases from the hands of the State into the hands of the procedural parties involved, however, causes the distortions in the fundamental interests of the whole society, the inconsistent approach to individual citizens, their unequal position. The possibilities of the injured party and the accused directly influence the form of criminal proceedings and participate in the decision-making process cause that the concept of justice assumes completely different content (nature).

A significant weakening of the state's influence on the resolution of the criminal dispute and the strengthening of the autonomy of the individual parties can threaten the legal stability of society and the State. As the State assumed the commitment to protect its citizens without distinction and to promote the fundamental values of society, the extensive privatization of criminal justice would prevent the State from its due and consistent fulfillment of this commitment. The arbitrary decision-making by the parties on criminal prosecution, their arbitrary creation of a final decision on the matter would seriously jeopardize the equal treatment of citizens and the proper functioning of the democratic State following the rule of law.

Regarding the philosophy of negotiated justice (plea bargain agreement) as one of the most widespread manifestations of the philosophy of the privatization of criminal justice, the reasons for which we regard this philosophy as more than problematic (in the context of our continental legal system) are many. In the first place, the agreement as a bilateral legal act is typical of the private sector in particular. However, guilt and punishment can never be the subject of an agreement, as the criminal law is typical of subordination nature, and the State is the exclusive holder of the criminal monopoly. The law enforcement authorities that are acting in the position of superiority against the accused are therefore justified and obliged to make the authoritative decisions that the subordinate subject must always respect.

Another reason, for which the philosophy of negotiated justice can be considered to be problematic, stems from the system of principles applied in continental criminal proceedings. In the Slovak criminal proceedings, "the search principle" and "the principle of properly establishing the facts of the case that do not give rise to reasonable doubts"14 still apply. That results in the fact that the bodies involved

14 Pursuant to Section 232 of the Slovak Code of Criminal Procedure, the search principle means that the law enforcement authorities are acting ex officio, and with the same care they have to thoroughly clarify the circumstances regardless of whether they prejudice or benefit the accused and they shall take evidence in both these directions without waiting for the motion of the parties. Pursuant to Section 232 of the Slovak Code of Criminal Procedure, the principle of properly 
in criminal proceedings (and the court) must proceed so as to properly establish the facts of the case that do not give rise to reasonable doubts, to the extent necessary for making the decision. They must procure the evidence as part of their official duties. They must thoroughly clarify the circumstances regardless of whether they prejudice or benefit the accused, and they must take the evidence in either direction so as to enable the court to arrive at a fair decision. ${ }^{15}$ However, the philosophy of negotiated justice is marked by certain conflicts, risks. Musil, for example, states that "pleading guilty of the accused creates a fiction of the established truth, the court may take evidence that is proposed or contained in the indictment (in the motion) or submitted by either party." At the same time, the author states that "the reality of judicial practice in all countries where plea bargain agreements are established, convincingly shows that such verification of the truth of the confession is either not exercised at all or is completely formal" (2008). Experience, not only from the Anglo-American legal system, shows that there are often cases of a false guilty plea and subsequent lapses of justice. There are several reasons for false confessions, most often being done for fear of imposing a possible more severe punishment when conducting the due criminal procedure.

As has already been pointed out above, it is also very questionable whether an agreement on the punishment actually leads to the achievement of the basic functions (purpose) of punishment. It is questionable whether the negotiated punishment actually ensures the protection of society against criminals so that the citizens can live in society safely and that society can function properly. The philosophy of negotiated justice in relation to punishment and its purpose brings many questions. Does the negotiated sentence prevent the sentenced person from committing another criminal activity? Does the negotiated punishment change the real attitude of the perpetrator of a crime in the sense that the perpetrator is intimidated and finds criminality committed in the future to be disadvantageous? Does the negotiated punishment create the conditions for the education of a convicted person to lead a proper life? Does the negotiated punishment ensure the deterrence of other potential offenders from committing the crime? Does the negotiated punishment affirm the feeling of legal certainty and justice in other members of the society? Is a negotiated punishment in the form of a punishment reduced under the law's predicted penal sanction a real expression of the societal moral conviction of a perpetrator? Is it a legal and ethical negative evaluation of the offender and his unlawful act?

In our view, the philosophy of negotiated justice does not lead to the fulfillment of the basic functions of the punishment. In the context of its functions, the negotiated punishment has the opposite effect. The negotiated sentence may cause the perpetrator to reassure him that in the case of another unlawful act he will make an agreement with the State again, and everything will be "settled somehow". As a consequence, the perpetrator loses fear of the State's "anger" in the event of his criminal activity and the subsequent strict approach of the State to holding responsibility in terms of existing penal sanctions. This can be supported for instance by the existing cases of many ultra-nationalist politicians who, once convicted of hate speech, are committing acts like they would in the past again without fear of prosecution (Tudoroiu et al. 2009). It should be emphasized that the philosophy of negotiated justice can be applied not only in the cases of less serious criminal offenses (minor offenses) but also in the cases of serious offenses_crimes (on a theoretical level e.g., in the cases of crimes such as robbery, killing, second-degree murder) ${ }^{16}$ when the use of an agent is necessary to detect the criminal

establishing the facts of the case that do not give rise to reasonable doubts means that a decision on guilt and conviction of an accused may only be made if there are no reasonable doubts about the facts eastablishing his guilt. The decision on guilt and punishment is therefore only possible after a careful, objective and impartial evaluation of all available evidence. If doubts arise, it is necessary to deliver an acquittal.

15 See Section 2 sect. 10 of Criminal Procedure Code no. 301/2005 Coll. de lege lata.

16 In this context, we can mention one of the infamous cases of crime prosecution, in which the philosophy of negotiated justice was applied in a rather absurd way. In concreto, this was the case of a well-known Colombian drug lord and narcoterrorist named Pablo Escobar, who, on the basis of an agreement with the State in 1991, confessed to the crime and voluntarily surrendered. The benefit received by Pablo Escobar was the imposition of a five-year prison sentence in the La Catedral detention facility, which, on the basis of a negotiated agreement with the State, had been designed and built by Escobar. In fact, it was a luxury hotel that was far from a regular prison cell. It should be added that Escobar confessed only to a 
offense committed (Čentéš and Beleš 2018). A negotiated punishment may also have the opposite effect on society itself. If the society sees that the perpetrators of criminal offenses are negotiating their criminal offense and punishment with the State, i.e., negotiating the terms of the confessing (pleading guilty), confidence of the society in the ability of justice to properly deal with the crime may be weakened. Members of the society may assume the impression that justice is just a conceived concept without real content, and what is really important is the ability to negotiate with the State concessions or benefits. This may be particularly evident in the case of economic/white collar crimes, or crimes related to the use of the computer and the online world (for instance in relation to new forms of virtual money) (Šimonová et al. 2019). Thus, society assumes the conviction that an adequate penalty does not have to be the real consequence of the unlawful act. Gradually, the basic principles of the rule of law and the trust of citizens not only in justice but also in the State itself can be weakened. A weakening of the principle of legal certainty may ultimately result in the erosion of civil society, disrupting human relationships.

\section{Negotiated Justice: Only Doctrinal Problem?}

For many, negotiated justice can only seem to be a doctrinal problem. The truth is that, from the perspective of a pragmatic approach of legal professions, negotiated justice is a generally accepted, popular and applied way of dealing with criminal cases. On the basis of assessing the practical interests of the various procedural entities (subjects), it can be stated that the privatization of criminal proceedings appears to be subjectively beneficial to all the parties (subjects) involved. The first and main subject to benefit significantly from the transfer of a dispute from the hands of the State to the hands of the directly aggrieved parties is the accused himself. Indeed, many of the legal institutions that are in favor of the privatization of criminal proceedings allow the accused directly to avoid criminal prosecution before a court and imposition of an adequate or severe penalty. In privatized criminal proceedings, the imposition of a sentence on the accused is not, in principle, the result of the single-sided (authoritative) activity of the State, but is mostly the result of the bilateral activity of the injured and the accused. Each of these parties strives to ensure maximum satisfaction of their individual interests and therefore the final decision is to some extent a certain consensual product of the whole proceeding (conciliation, agreement on guilt and punishment, conditional cessation of criminal prosecution). From this point of view, it can be stated that the privatization of criminal proceedings brings subjective benefits also for the victim himself/herself. Sometimes, this may lead to compensation for the damage suffered by the offense in a more moderate manner than in the case of a prosecutor's prosecution, which can only intensify the conflict between the accused and the victim. ${ }^{17}$ However, it should be noted, that this happens only in a minority of cases. Besides that, it should be added that in many criminal cases where there is a particularly close relationship between the injured and the perpetrator (e.g., domestic violence cases), it is extremely difficult to imagine that the perpetrator and the injured shake hands, settle their dispute and thus close the criminal case (Polák 2017).

However, in terms of the practical exercise of legal professions and the day-to-day solution of a number of criminal matters, privatization is also subjectively beneficial for other criminal proceedings subjects. In this sense, the transfer of the resolution of criminal cases from the public area to the private area is also beneficial for the state authorities involved in the prosecution. Indeed, if a certain range of criminal cases becomes private, prosecutors and judges are relieved of a number of less serious cases and may subsequently pay more attention to more difficult and serious cases. Last but not least, the

relatively insignificant crime. He expected that the execution of a negotiated punishment will finish the hunting of the competent authorities on his person. In this example, it can be seen to what absurd and extreme forms the philosophy of negotiated justice can lead. Of course, in the example illustrated, the criminal justice approach had absolutely nothing to do with real justice and fair punishment (fair execution of punishment).

17 In the case of far-reaching privatized criminal proceedings, the injured party is able, even by his own procedural activity, to remedy the injured interests, even if the authorities of the State refuse to take action or prosecute. 
privatization of criminal proceedings also has a significant impact on the work of lawyers (advocates, barristers) themselves (Klimek 2015). We even believe that private lawyers (advocates, barristers) are among those whose profits from the transfer of a criminal case from the public area to a private area are as great as possible. Experience from other countries also confirms that the rising tendency of transferring the dispute into the hands of both the accused and the injured leads to an increase in demand for law firm services. Not all accused and victims have the necessary legal knowledge and capacity to participate actively in the prosecution. This, of course, creates room for the involvement of lawyers who are able to assist the subjects in a qualified manner. However, the advantage of the privatization of criminal proceedings lies not only in the increased frequency of legal services provided by lawyers but also in the remuneration for participation and preference for the institutions of privatized criminal justice. In this connection, we can mention that the law ${ }^{18}$ stipulates that if an agreement on guilt and punishment has been approved by the court before filing an indictment, the lawyer is entitled to (besides the remuneration for procedural acts performed in criminal proceedings) a remuneration in the amount of quadruple of the basic rate of tariff remuneration for one act of legal service. It can be stated that this advantage is certainly one of the most motivating advantages for each lawyer for the application of the institutions of privatized criminal justice.

As can be seen, all parties (subjects) involved in the criminal proceedings benefit from the privatized criminal proceedings. Nevertheless, we are of the opinion that criminal law, which belongs to the branches of public law, is not inherently and should not be primarily concerned with the interests of individual parties (subjects) to criminal proceedings. In the first place, criminal law should promote the public interest, which is interest in achieving real justice. The main objective is to ascertain, without reasonable doubt, whether the offense was committed and if so, to identify the real offender and to impose a fair and proportionate penalty or protective measure by law, then to enforce the decision or to guarantee its enforcement. At the same time, the aim of this legal branch is to strengthen the rule of law, to prevent and stop crime and to educate citizens to respect the legislation, human rights and fundamental freedoms. Unfortunately, as mentioned above, the philosophy of negotiated justice does not really achieve these goals or always lead to the fulfillment of these tasks. That is why we are of the opinion that alternatives to individual elements of privatized criminal justice should be sought, which will realistically and without reasonable doubt lead to the achievement of the objectives of criminal proceedings and the public interest in reaching justice.

\section{Conclusions}

The philosophy of negotiated justice represents a relatively new approach to dealing with criminal cases, the purpose of which is to simplify and speed up criminal justice, and to eliminate the problem of overloaded courts. The truth is, however, that one of the accomplices in the present state of criminal justice is just the legislator himself. The legislator seeks to solve all problem situations, particularly through criminal law institutions. It may be from his ignorance, but perhaps in an effort to catch the fancy of the voters. This approach, which is particularly apparent in Central European countries, also has its name: penal populism. So, the reality is that in the case of not knowing or not wanting to deal with minor offenses, the legislator criminalizes them and (naively) expects them not to occur more. This situation plays an important role in the philosophy of negotiated justice, which ensures a fairly simple handling of criminal matters. For the perpetrator, it is easier to quickly plead guilty and accept less severe punishment than to risk a proper punishment imposed by the court. Therefore, plea bargain agreement de facto represents a means of extremely easy achievable criminal repression.

However, one may ask whether it is really necessary to constantly affect the members of society by repressive means. Is this approach not a sign of totalitarian regimes? A high degree of criminalization

18 Section 14 sect. 7 of the Decree of the Ministry of Justice of the Slovak Republic no. 655/2004 Coll. on lawyers' fees and reimbursement for legal services. 
is, in our view, contrary to the European philosophy of criminal law as "last possible means" (ultima ratio). It should be noted that the state of crime (in particular its extent and structure) and, consequently, the overall state of criminal justice depends largely on the extent of the criminalization, i.e., on that, which acts are considered by the society to be so harmful and unacceptable that they are considered to be criminal offenses. Criteria for this harmfulness and unacceptability are different in different countries (Karabec 2012). In general, however, it can be stated that the primary task when ascertaining the scope of criminalization is to identify which conduct is morally wrongful (Simester and von Hirsch 2011; Simester et al. 2019). We do not think it is beneficial if the society becomes too punitive. The result of excessive criminalization is the deterioration of overall social climate, changes in the societal moods and gradual disruptions of relations among the members of society. Especially dangerous is a too punitive approach in relation to juvenile offenders committing illegal acts in the internet environment, the gravity of which is negligible in many cases. On many issues, young people have little information and paradoxically they are not trying to get this information on their own (Mihálik 2016). However, the criminal sanctioning of these persons has serious consequences for their future position in society.

For these reasons, we hold the view that a more appropriate and acceptable way is the way of wider application of the philosophy of decriminalization and depenalization. It is this legal philosophy that is applicable to our criminal justice system, and at the same time, it makes it possible to naturally reduce the level of crime and hence the overloading of criminal justice. The philosophy of decriminalization and depenalization is based on the idea that criminal justice authorities should limit their interventions to delinquents only to those situations which really threaten the most important values of human society and when it is really necessary to exercise criminal prosecution. In most cases, the resulting effect of criminal justice intervention is not the elimination of negative anti-social phenomena, but rather, infliction of long-term negative consequences not only to the offender but ultimately to the society itself. This is based on the knowledge that when a delinquent comes into contact with the criminal justice system, he will carry its seal until the end of his life. This interferes not only with his personal and family life but causes also his separation from regular social activities. (Siegel 2010) notes that such official labeling develops negative characteristics of the offender, it does not remove his anti-social tendencies.

We suppose that the philosophy of decriminalization and depenalization is one of the most effective ways of reducing the number of cases that criminal justice has to deal with and at the same time eliminating the danger of stigmatization of the perpetrator. Both means of simplifying the criminal justice are being used in many European countries and make a real contribution to improving the functioning of criminal justice systems and reducing their overload. Decriminalization can have two basic forms - it can be material decriminalization and procedural decriminalization. Material decriminalization is a reclassification of the offense from a criminal offense to a misdemeanour (administrative offense). In this event, the case is handled by public administration authorities, not criminal justice authorities. Procedural decriminalization, on the other hand, means that the act is still formally a criminal offense, but is handled by non-criminal institutions (public administration authorities) which may impose a fine. Regarding depenalization, this process is in part similar to procedural decriminalization, as the act formally also remains a criminal offense. The difference, however, is that the criminal justice authorities do not accede to its punishment (Jehle and Wade 2006). We suppose that any of these forms is also applicable within our legal order.

However, decriminalization or depenalization is not a flawless means. It must be emphasized that, despite their positive aspects, both means of simplifying criminal justice also lead to some unresolved questions or complications. The problem may, in particular, be the question of further handling the decriminalized act. Handling the case by public administration authorities may increase the risk of an unfair appraisal. This is due to the fact that the administrative proceedings do not have as sophisticated rules as criminal proceedings and it can happen that the administrative sanctioning will not fully correspond to the committed act. Improving the administrative law must, therefore, go hand in hand with the process of decriminalization or depenalization. At the same time, it may be difficult 
to establish a dividing line between an act that needs to be decriminalized and an act that should be dealt with under the criminal justice system. Criteria for deciding this dispute can be set in different ways-decriminalization may therefore, for example, be based on the frequency of committing a crime, its occurrence, existing values of society. Before decisions on acceding to decriminalization or depenalization, it is necessary to resolve all of the above issues. However, it should be noted that although their solution is not easy, it is not impossible.

Author Contributions: Conceptualization, B.Š.; Data curation, D.G. and J.M.; Formal analysis, B.Š., and D.G.; Funding acquisition, B.Š.; Investigation, D.G. and J.M.; Methodology, B.Š. and J.M.; Project administration, B.Š.; Resources, D.G. and J.M.; Validation, J.M.; Visualization, D.G.; Writing—original draft, B.Š.; Writing一review \& editing, B.Š., D.G. and J.M. All authors have read and agreed to the published version of the manuscript.

Funding: This research received no external funding.

Conflicts of Interest: The authors declare no conflicts of interest.

\section{References}

Benson, Bruce. 1996. Privatization in Criminal Justice. Oakland: The Independent Institute.

Bureš, Oldřich. 2013. Privatizace bezpečnosti: České a zahraniční zkušenosti (Privatization of security: Czech and foreign experience). Praha: Grada Publishing.

Čentéš, Jozef. 2008. Poznatky z uplatňovania prípravného konania po 1. 1. 2006. Predsúdne konanie (Findings from the Application of Pre-Trial Proceedings after 1.1.2006. Pre-Trial Proceedings). Bratislava: Akadémia PZ.

Čentéš, Jozef, and Andrej Beleš. 2018. Regulation of agent as a tool for combating organized crime. Journal of Security and Sustainability Issues 8: 151-60.

Čentéš, Jozef, and Anna Magvašiová. 2008. K aplikácii inštitútu konania o dohode o vine a treste (On the application of the institution of agreement on guilt and punishment). Trestněprávní Revue 7: 15-18.

Eser, Albin. 1993. Funktionswandel strafrechtlicher Prozeßmaximen: Auf dem Weg zur "Reprivatisierung" des Strafverfahrens (Functional Change of Criminal Procedural Maxims: On the Way to "reprivatisation" of Criminal Proceedings). Heidelberg: Müller.

Horváth, Peter, Lukáš Cíbik, and Martin Švikruha. 2018. Finančná závislost' územnej samosprávy na Slovensku (Financial dependency of territorial self-government in Slovakia). Scientific Papers of the University of Pardubice, Series D 25: 67-79.

Jehle, Jörg-Martin, and Marianne Wade. 2006. Coping with Overloaded Criminal Justice Systems: The Rise of Prosecutorial Power Across Europe. Heidelberg: Springer.

Jesenková, Adriana, and Michal Jesenko. 2015. L'udské práva ako projekt vzájomnej dôvery—antifundacionalistický pohl'ad na l’udské práva. L'udské práva. Kam kráčaš demokracia (Human Rights as a Project of Mutual Trust-Antifundationalist View of Human Rights. Human Rights. Where You Go Democracy). Košice: Univerzita Pavla Jozefa Šafárika v Košiciach.

Karabec, Zdeněk. 2012. Poznámky k trestní politice (Notes on criminal policy). Kriminalistika 1: 3-22.

Klimek, Libor. 2015. European Arrest Warrant. Cham: Springer.

Klimek, Libor. 2017. Mutual Recognition of Judicial Decisions in European Criminal Law. Cham: Springer.

Kobor, Susanne. 2008. Bargaining in the Criminal Justice Systems of the United States and Germany: A Matter of Justice and Administrative Efficiency within Legal, Cultural Context. Frankfurt am Main: Peter Lang.

Küng-Hofer, Rolf. 1984. Die Beschleunigung des Strafverfahrens unter Wahrung der Rechtsstaatlichkeit (Acceleration of Criminal Proceedings While Respecting the Rule of Law). Bern and Frankfurt/M.: Lang.

Magvašiová, Anna, and Jozef Čentéš. 2008. Poznatky z aplikácie konania o dohode o vine a treste. Rekodifikácia trestného práva-doterajšie poznatky a skúsenosti (Findings from the Application of the Agreement on Guilt and Punishment Proceedings. Recodification of Criminal Law-Knowledge and Experience to Date). Bratislava: Bratislavská vysoká škola práva.

Mandalík, Radoslav. 2006. K inštitútu konania o dohode o vine a treste (On the institution of proceedings for an agreement on guilt and punishment). Justičná revue: Časopis pre právnu prax 58: 1611-13. 
Marková, Martina. 2005. Odklony—alternatívne spôsoby riešenia trestných vecí a ich význam pre racionalizáciu trestného konania $i v$ súvislosti so zavádzaním prokov oportunity do Trestného poriadku. Súkromné a verejné právo súčasnosti (Diversions-Alternative Ways of Solving Criminal Cases and Their Importance for the Rationalization of Criminal Proceedings and in Connection with the Introduction of Discretion Elements into the Code of Criminal Procedure. Private and Public Law Today). Trnava: Facultas Iuridica Universitas Tyrnaviensis.

Mihálik, Jaroslav. 2016. When electoral Paradigm meets the research Implications: The Youth Perspective. Slovak Journal of Political Sciences 16: 335-52. [CrossRef]

Mihálik, Jaroslav, Peter Horváth, and Martin Švikruha. 2019. Give me liberty or give me money: The fiscal decentralization and autonomy of regional governance in Slovakia. European Journal of Government and Economics 8: 96-109. [CrossRef]

Musil, Jan. 2008. Dohody o vině a trestu—ano či ne? Rekodifikácia trestného práva—doterajšie poznatky a skúsenosti (Agreements on Guilt and Punishment-Yes or No? Recodification of Criminal Law-Knowledge and Experience to Date). Bratislava: Bratislavská vysoká škola práva.

Musil, Jan, Vladimír Kratochvíl, and Pavel Šámal. 2003. Kurs trestního práva: Trestní právo procesní (Course of Criminal Law: Criminal Procedural Law). Praha: C. H. Beck.

Pipek, Jiří. 2000. Oficiální nebo dalekosáhle privatizované trestní řízení (Official or far-reaching privatized criminal proceedings). Právnik 139: 1144-81.

Polák, Peter. 2017. Pomoc obetiam násilia. Kriminologické možnosti riešenia domáceho násilia (Helping Victims of Violence. Criminological Possibilities of Solving Domestic Violence). Bratislava: Wolters Kluwer.

Prusák, Jozef. 2001. Teória práva (Theory of Law). Bratislava: Vydavatel'ské oddelenie PF UK.

Šámal, Pavel. 1999. Základní zásady trestniho řízení v demokratickém systému (Basic Principles of Criminal Proceedings in a democratic System). Praha: ASPI Publishing.

Siegel, Larry. 2010. Essentials of Criminal Justice. Belmont: Cengage Learning.

Simester, Andrew, and Andreas von Hirsch. 2011. Crimes, Harms, and Wrongs: On the Principles of Criminalisation. Oxford: Hart Publishing.

Simester, Andrew, John Spencer, Findlay Stark, George Sullivan, and Graham Virgo. 2019. Simester and Sullivan's Criminal Law: Theory and Doctrine. Oxford: Hart Publishing.

Šimonová, Jana, Jozef Čentéš, and Andrej Beleš. 2019. Financial analysis of innovative forms of money. Entrepreneurship and Sustainability Issues 7: 69-80. [CrossRef]

Sojka, Stanislav. 2008. Dohoda o vine bez dohody o treste a hlavné pojednávanie ( 232 ods. 4 Tr. por.) (The agreement on guilt without agreement on punishment and the main hearing ( $\$ 232$ sect. 4 of the Criminal Procedure Code)). Justičná revue: Časopis pre právnu prax 60: 283-84.

Sosnowska, Małgorzata, Piotr Szymaniec, and Ewa Tuora-Schwierskott. 2017. Religionsfreiheitsraum im Polen, Tschechien und im Deutschland. Rechtliche Analyse (Religious freedom in Poland, the Czech Republic and Germany. Legal analysis). Wałbrzych: Wydawnictwo Uczelniane Państwowej Wyższej Szkoły Zawodowej im. Angelusa Silesiusa.

Szymaniec, Piotr. 2017. Koncepcje wolności religijnej. Rozwój historyczny i wspótczesny stan debaty w zachodniej myśli polityczno-prawnej (Concepts of Religious Freedom: Historical Development and the Present Status of Debate in Western Legal and Political Thought). Wrocław: Oficyna Wydawnicza Atut-Wrocławskie Wydawnictwo Oświatowe.

Tudoroiu, Theodor, Peter Horváth, and Marek Hrušovský. 2009. Ultra-Nationalism and Geopolitical Exceptionalism in Mečiar's Slovakia. Problems of Post-Communism 56: 3-14. [CrossRef]

Vráblová, Miroslava. 2007. Niekol’ko poznámok k historicky najmladšiemu odklonu v slovenskom trestnom konaní-dohode o vine a treste (Some remarks on the historically youngest diversion in Slovak criminal proceedings—-the guilt and punishment agreement). Trestněprávní Revue 6: 192-96.

Žilinka, Maroš. 2006. K alternatívnym spôsobom vybavenia trestných vecí podl'a zákona č. 301/2005 Z.z. Trestný poriadok (On the alternative methods of handling criminal cases under the Act no. 301/2005 Coll. Criminal Procedure Code). Justičná Revue: Časopis pre právnu prax 58: 199-203.

(C) 2020 by the authors. Licensee MDPI, Basel, Switzerland. This article is an open access article distributed under the terms and conditions of the Creative Commons Attribution (CC BY) license (http://creativecommons.org/licenses/by/4.0/). 